930.85(497.4:497.11)

https://doi.org/10.18485/kud_kp.2018.ch8

\author{
проф. др Маја Ђукановић \\ Универзитет у Београду \\ Филолошки факултет
}

\title{
СРПСКО-СЛОВЕНАЧКЕ МЕЪУКУЛТУРНЕ СТУДИЈЕ КРОЗ ПРИЗМУ УРБАНЕ МИКРОТОПОНИМИЈЕ БЕОГРАДА
}

\section{Сажетак}

Београд, као значајан културни центар на Балкану привлачио је многе - од уметника и научника који су дошли развијајући своју каријеру, до људи који су се досељавали у потрази за бољом свакодневицом. Историјске околности су се мењале, политички системи су се смењивали, мењале су се границе заједничке државе, а након више од седам деценија постојања у заједничкој држави, Срби и Словенци су наставили свој развој у одвојеним ентитетима. Током периода проведеног у заједничкој држави, узајамно су оставили препознатљив траг не само у области културе и уметности, него је међусобни утицај приметан и у другим сферама живота. Преплитања и међусобни утицаји српске и словеначке културе и уметности обухватају бројне примере из различитих подручја стваралаштва - књижевности, музике, сликарства, позоришта, филма - од којих ће у овом раду бити представљен само мањи део.

Кључне речи: Београд, култура, уметност, књижевност, српско-словеначке међукултурне студије 


\section{1. Увод}

Београд је скоро читав век био престоница народа који су чинили некадашњу заједничку државу Југославију. Као значајан културни центар на Балкану, привлачио је многе - од уметника и научника који су дошли развијајући своју каријеру, до људи који су се у Београд досељавали у потрази за бољом свакодневицом. Као престоница Краљевине Срба Хрвата и Словенаца (1918-1929) односно Краљевине Југославије (19291945), затим Демократске Федеративне Југославије (1945-1946), Федеративне Народне Републике Југославије (1946-1963) односно Социјалистичке Федеративне Републике Југославије (1963-1992), а касније и као престоница Савезне Републике Југославије (1992-2003), Србије и Црне Горе (2003-2006) и Србије (од 2006), Београд је постао дом људима из различитих крајева, који су га обогатили својим културним наслеђем.

Историјске околности су се мењале, политички системи су се смењивали, мењале су се границе заједничке државе, а након више од седам деценија постојања у заједничкој држави, Срби и Словенци су наставили свој развој у одвојеним ентитетима. Током периода проведеног у заједничкој држави, узајамно су оставили препознатљив траг не само у области културе и уметности, него је међусобни утицај приметан и у другим сферама живота. У културном идентитету оба народа може се, наравно, препознати традиција коју су са собом донели и досељеници из других историјских окружења.

Бројке из пописа становништва сведоче да су се Словенци од свих подручја у Србији најчешће досељавали и настањивали у Београду: 1921. године било их je 1.059 , затим се 1931. године број повећао на 5.986, а према пописима после Другог светског рата Словенаца 
је у Београду било око 10.000. У време тзв. “југословенства" било је тешко пратити званични број Словенаца у Србији, јер су се многи изјашњавали као Југословени, а пре свега то важи за децу рођену у мешовитим браковима (Кржишник - Букић 2003: 126).

\section{2. Формирање културног идентитета} на преласку из 19. у 20. век

Културни идентитет савременог српског друштва заснива се у великој мери, као и културни идентитет других савремених друштава, на прожимањима и међусобним утицајима различитих баштина и традиција. У српској култури током ослобађања од вишевековне турске власти и после овог процеса, током 19. века и на преласку у 20. век, долази до бурних промена на плану стварања њеног новог идентитета, формирањем новог, урбаног друштва чија се грађанска класа окреће западноевропској традицији. Овај процес се препознаје не само у различитим гранама уметности, него и у свакодневном животу града: развија се позоришна уметност, формира се опера, оснивају се певачка друштва и хорови. Велику популарност доживљавају такозвани „комади с певањем“, чије извођење изискује формирање певачких друштава и хорова, у то време нових у Србији. Развој позоришта, опере, стварање певачких друштава и хорова условило је и потребу за писањем одговарајућих композиција, као и за оспособљавањем и школовањем извођача. Композиције су често писане на основу књижевних текстова, а омиљене су биле оне које су садржале мотиве и описе догађаја и личности од значаја за српску историју (Ђукановић 2015 : 112).

Период заједничке државе у којој су се, између осталих, налазили и Срби и Словенци, обухвата скоро 
читав 20. век, али се заснива на културним везама које су почеле да се стварају још у 19. веку. Цео 19. век, а особито његову другу половину, карактеришу драматичне промене које су обухватиле и српско и словеначко друштво. На територији Србије се у том периоду стварала независна, национална држава, са сопственом националном културом, а грађанска класа која је била у повоју стварала је основе урбане културе и окретала се еворпским узорима, ослобађајући се од турске власти. Градови у Србији постају својеврсни центри европеизације, а у томе је предњачио Београд, који се 1867. године потпуно ослободио присуства турске војске и администрације (Норис 2002: 131).

За српско грађанство тог времена карактеристична је одлучност да се ослободи атмосфере оријенталног и да у кратком року уведе приметне промене. (Норис 2002: 119-149; Стојановић 2008). Што се тиче демографске слике, током 19. века је забележен значајан прилив имиграната из различитих крајева. Шездесетих година 19. века Београд је, на пример, имао 20.000 становника, а један век касније, почетком 20. века, у Београду је живело око 90.000 становника (Прошић-Дворнић 2006: 108). У Београд су се у овом периоду досељавали најчешће Срби из других крајева, а може се рећи да су по бројности на другом месту били становници из Аустроугарске - поред Аустријанаца, Чеха, Јевреја, Италијана међу њима су били и Словенци. Реч је махом о људима који су у Србију долазили са одређеним образовањем и/или капиталом, који су у то време Србији недостајали. Процеси њихове интеграције ни у ком случају нису били једносмерни, што је и иначе карактеристика оваквих пресељавања. Већина ових имиграната била је веома лепо прихваћена у новој средини, а њихова асимилација се махом завршила по- 
тпуном асимилацијом и само далеким сећањем на другачије порекло (Прошић-Дворнић 2006: 95-99).

\section{3. Досељавање Словенаца у Београд у периоду заједничке државе}

Присуство Словенаца у Београду било је најприметније у периоду после Другог светског рата, и то у различитим областима - долазили су научници различитих профила, политичари, уметници, али и људи који су обављали једноставније послове (Кржишник Букић 2003: 125-126). Један део ових досељеника дошао је још пре рата, и у Београду се још тада усталио, оформивши своје породице, а други део су чинили они који су се доселили после 1945. године, стварајући један нови идентитет у заједничкој држави.

Уметници који су крајем 19. и почетком 20. века у Београд дошли са територије данашње Словеније, а међу њима су најбројнији били они из области музичке уметности, али исто тако и Словенци који су се у Београд, а и друге крајеве Србије досељавали вођени другим професијама, у великој мери су допринели стварању нераскидивих веза између два народа. У периоду заједничке државе створена је и развијала се заинтересованост за језик и књижевност оног другог језичког подручја, а уметници и научници су сарадњу развијали и боравећи на школовању и стручним усавршавањима у иностранству, што важи пре свега за књижевнике и сликаре.

На пример, у славном минхенском атељеу словеначког сликара Антона Ажбеа (1862-1905) за студије на минхенској Ликовној академији су се припремали бројни сликари, међу њима српске сликарке Надежда Петровић и Бета Вукановић, заједно са Словенцима Рихардом Јакопичем, Матијом Јамом и Иваном Грохаром. 
Ова сарадња је изнедрила значајан, како уметнички, тако и друштвено ангажован просветитељски траг у земљама из којих су потекли. Били су надахнути пансловенским идејама, а заједничка им је била и жеља да својим сународницима пруже нова сазнања оснивајући различите сикарске институције. Рихард Јакопич рецимо у Љубљани оснива Уметнички павиљон, а Бета и Риста Вукановић оснивају у Београду Високу уметничку школу, што је имало велики позитиван утицај на даљи развој сликарства на овим просторима (Стеле 1974 : 267-278).

Поред музике и сликарства, за своја достигнућа и рад су заинтересованост показивали и књижевници који су потицали из словеначког и српског језичког окружења. То је утицало и на заинтересованост за учење словеначког и српског језика, као и превођење књижевних дела. Већ на самом почетку 20. века, професор српске књижевности, Павле Поповић, одржава курсеве словеначког језика и словеначке књижевности, намењен будућим књижевним преводиоцима (Ђукановић 2015 : 77). Све ово утицало је на међусобну повезаност српског и словеначког народа, преплетеност и међусобно познавање српске и словеначке културе.

\section{4. Елементи словеначке културе у урбаној микротопонимији Београда}

\section{1. Називи улица}

Током постојања у заједничкој држави у Београду многе улице и тргови добили су име по неком од словеначких писаца, научника или уметника, а има и оних који су названи по неком словеначком географском појму - области, граду, планини или реци, а има и улица названих према појмовима и личностима из народноослободилачке 
борбе односно Другог светског рата. Од словеначких писаца на списку београдских улица заступљени су: Мишко Крањец (1908-1983), Карл Дестовник Кајух (1922-1944), Франце Прешерн (1800-1849), Иван Тавчар (1851-1923), Фран Салешки Финжгар (1871-1962), Франце Бевк (18901970), Фран Левстик (1831-1887), Иван Цанкар (18761918), Антон Ашкерц (1856-1912), Валентин Водник (1758-1812), Отон Жупанчич (1878-1949), а ту су и језичари Јернеј Копитар (1780-1844) и Примож Трубар (15081586). На таблама стоје натписи: Мишка Крањца, Кајухова, Прешернова, Тавчарева, Финжгарова, Франца Бевка, Франа Левстика, Франца Прешерна, Цанкарева, Антона Ашкерца, Валентина Водника и Отона Жупанчича, затим улица Јернеја Копитара, Копитарева градина и Трубарева улица. На списку се налази и улица глумице Веле Нигринове. Три улице у Београду носе словеначка имена из периода Народноослободилачке борбе: Похорских батаљона и народних хероја из Другог светског рата - Франца Розмана и Тонета Томшича. Има улица које носе имена словеначких предела, односно географских појмова: према градовима Цеље, Љубљана, Толмин и Горица изведени су називи улица Цељска, Љубљанска, Толминска и Горичка; према језерима Бледска и Бохињска; према областима у Словенији Випавска, Горењска, Долењска, Белокрањска; и према планинама Похорска и Триглавска (Ђукановић $2015: 128$ ).

\section{2. Називи школа}

О живој повезаности између српске и словеначке културе и науке, говори и чињеница да у Београду постоје и три школе које носе имена познатих Словенаца: основна школа “Франце Прешерн”, основна школа “Антон Скала” и музичка школа “Даворин Јенко”. 
Основна школа „Франце Прешерн” је основана још 1938. године као четворогодишња школа под именом Очигледна школа „Кнеза намесника Павла“. Школске 1951/52. године преименована је у Основну школу „Франце Прешерн“, а име је задржала и по пресељењу у нову зграду 1969. године. Школа је добила име по највећем словеначком песнику, аутору „Сонетног венца”, епа „Крштење на Савици”, збирке „Поезије" и многих других познатих песничких остварења, чије је дело значајан елемент заједничке југословенске културне баштине. Прешерна историчари књижевности називају првим и највећим словеначким књижевним класиком, чије песничке идеје, форма и стил чине хармоничну целину, а теме којима се бави су повезане са свакодневним искуствима блиским читаоцу.

Још једна београдска основна школа носи име једног "београдског” Словенца, професора Антона Скале. Основна школа „Антон Скала” названа је према једном од пионира дефектологије, који је од 1930. па све до своје смрти 1968. године живео и радио у Београду, најпре у Министарству просвете као саветник за специјално школство, а затим на Вишој педагошкој школи и Филозофском факултету у Београду, где се посветио питањима васпитања деце и омладине са посебним потребама (Гспан 1967). Најзначајнијим делом професора Скале сматра се његова књига „О васпитавању деце ометене у развитку” (1959), а у својим чланцима посебно се посветио проблемима глувонемих, чиме је значајно утицао на савремени приступ овој проблематици. Школа “Антон Скала” основана је 1964. године и посвећена је образовању деце са лаком, умереном менталном ометеношћу и аутизмом. То је прва основна школа на Балкану која од 1978. године има одељење за децу са аутизмом. 
Име једног Словенца носи и музичка школа „Даворин Јенко". Она обухвата и основно и средње музичко образовање, а носи име великог композитора и диригента словеначког порекла, који је значајно утицао на развој музике у Србији крајем 19. и почетком 20. века. Као један од најутицајнијих уметника тог времена, Јенко је као капелник Народног позоришта у Београд позвао и велику глумицу, Велу Нигринову, чије име носи једна од београдских улица.

\section{3. Други урбани топоними}

У Београду постоје и други урбани микротопоними који су везани за рад Словенаца и њихов утицај на развој науке у Србији, а који не носе директно име оснивача. Једна од таквих институција је Дечја клиника, коју је основао и чији је први управник био др. Матија Амброжич (1889-1966), који је гимназију завршио у Љубљани, а студије медицине у Бечу, где је као изузетно успешан студент остао на месту асистента у славној бечкој педијатријској школи. По свом повратку у Љубљану, 1923. је основао Завод за социјално-хигијенску заштиту деце и прву Школу за медицинске сестре у Словенији, а у Београд се преселио 1926. године. Као професор на Медицинском факултету, Матија Амброжич се посветио педијатрији, пре свега са превентивног становишта, а уз велико лично залагање, успео је да оствари то да Дечја клиника добије сопствене просторије 1928. године. На клиници су, између осталог, биле запослене и медицинске сестре школоване у Љубљани, што је допринело даљем прожимању два народа.

Још једна значајна грађевина у Београду, односно лист који се у њој ствара, везана је за Словенце. Реч је о једном од најзначајнијих српских дневних листова, 
„Политици“, коју је 25. јануара 1904. покренуо Владислав Рибникар, Словенац. Његов отац, лекар Франц Рибникар, доселио се у Србију 1869. године, као млади хирург школован у Грацу. Са породицом је живео у Трстенику, Свилајнцу и Јагодини, а његов син Владислав je, по завршеним студијама у Београду, 1892. године отишао на даље школовање у Француску и Немачку. По повратку у Београд, 1904. године Владислав Рибникар је основао дневни лист „Политика“ и био је његов први уредник. Убрзо по избијању Првог светског рата, Владислав Рибникар је погинуо као припадник српске војске на фронту у западној Србији, што је била судбина и других Словенаца из Србије.

О свестраној сарадњи и културној размени између српске и словеначке културе после Другог светског рата сведочи и то што су неке од значајних београдских грађевина пројектовале словеначке архитекте. На пример, зграду Југословенског драмског позоришта је у сарадњи са архитектом Момчилом Белобрком конструисао словеначки архитекта Бојан Ступица. Његово име је познатије по трагу који је оставио у југословенској позоришној уметности, у којој је запамћено по томе што је Бојан Ступица био признати позоришни редитељ, а у историју Југословенског драмског позоришта је, осим као архитекта, уписан и тиме што је режирао представу „Краљ Бетајнове“, словеначког писца Ивана Цанкара, којом је позориште свечано отворено 3. априла 1948. На тај начин су остварена вишеструка преплитања, како различитих културних традиција - српске и словеначке, тако и различитих професионалних усмерења и знања једног ствараоца, Бојана Ступице, који се неизбрисиво уписао у културни идентитет Београда. У Југословенском драмском позоришту Ступица је окупио уметнике из свих крајева тадашње заједничке државе, Југославије (Гспан 1971). 
Средином 20. века, представе које је режирао Бојан Ступица биле су изузетно иновативне и имале су снажан одјек у јавности. Због тога је неколико година био у немилости власти, а радио је и у Љубљани и Загребу, уз велика међународна признања. Бојан Ступица је, по повратку у Београд крајем 50-их година, пројектовао и почео изградњу нове зграде Атељеа 212, у којем је био и руководилац. При крају своје каријере вратио се у Југословенско драмско позориште, у оквиру којег је изградио и своју трећу позоришну зграду, касније по њему названу „Театар Бојан Ступица“. Овај велики југословенски уметник, рођен у Љубљани, који је дуги низ година живео и стварао у Београду, оставио је неизбрисив траг у позоришном животу Србије, не само својим радом, него и утицајем на млађе генерације српских глумаца, режисера и драматурга (Ђукановић 2015 : 127).

За београдско Народно позориште нераскидиво је везано име глумице Веле Нигринове, чије име носи једна београдска улица. Словенка, рођене 1862. у Љубљани, Вела Нигринова је веома млада, са двадесет година, 1882. године дошла у Београд, на позив Даворина Јенка, тада већ познатог и утицајног уметника, припадника београдске интелектуалне елите. Перфектно савладавши српски језик, Вела Нигринова је већином наступала у трагедијама, играјући Јулију, Офелију, Сафо, Марију Стјуарт и сличне улоге, а гостовала је и у Прагу, Загребу, Софији и родној Љубљани (Лукман 1935). У историји српског позоришта њено име се наводи као једно од најважнијих, а стручњаци оцењују да је извршила значајан утицај на развој глуме крајем 19. и почетком 20. века у Србији. Живећи у Београду, постала је искрено посвећена Србији, а у прилог томе говори и чињеница да је за време српско-бугарског рата, током 1885. године, добровољно радила као болничарка, по- 
мажући српским војницима. Вела Нигринова је у Београду живела са Даворином Јенком, а њена смрт 1908. године га је оставила у дубокој тузи. Уз велике почасти је сахрањена у Београду, као једна од најзначајнијих српских глумица.

Када говоримо о Словенцима који су оставили значајан траг у урбаној микротопонимији Београда, треба поменути и словеначког архитекту светског реномеа, који у Београду није живео, али је по његовим нацртима изграђена црква Светог Антуна Падованског. Препознатљива по фасадној цигли, коју је Плечник користио и на другим својим грађвинама, црква Светог Антуна Падованског у својој основи има старохришћанску ротонду, чиме је аутор нагласио повезаност са основним вредностима хришћанства, желећи на тај начин да укаже на повезаност православне и католичке традиције. Унутрашњост цркве краси кип Светог Антуна, који је израдио познати вајар Иван Мештровић, а кип Богородице дело је Боже Пенгова, словеначког вајара. Наиме, по отварању самосталног архитектонског атељеа, у Бечу се дружио са Иваном Мештровићем и другим јужнословенским ствараоцима. Сарадњом ових познатих и признатих уметника Београд је обогаћен за још једно лепо и значајно здање. Изградња цркве Светог Антуна у Београду започела је 1929. године, на предлог самог Ивана Мештовића, који је са Плечником сарађивао још од студентских дана. После Плечникове смрти бригу за даљу изградњу цркве преузео је његов ученик, такође Словенац, архитекта Валентинчич, а изградња је завршена 1962. године (Ђукановић 2015 : 122-123).

\section{5. Словеначки музички ствараоци и Београд}

Све напред наведено сведочи да су од краја 19. века па до данашњих дана између Србије и Словеније ствара- 
не чврсте културне везе, које се и даље развијају. Међу Словенцима који су се досељавали у Србију, а посебно у Београд, било је много уметника, а међу њима су најбројнији били музичари. Они су и у сфери интерпретативне уметности, а још више као композитори утицали на развој музичке уметности у нашим крајевима. Зато у овом прилогу треба посебно нагласити њихову улогу у стварању српско-словеначких културних прожимања.

Иако је утицај композитора словеначког порекла у Србији веома значајан и несумњив о њиховом раду, стваралаштву и утицају на развој музичке уметности више је писано тек у последњих неколико година. У научним публикацијама је објављена неколицина радова (Сабо 2010 : 261; Прелић 2010 : 239; Ђукановић 2015 : 110), а пажња је посвећена пре свега развоју хорске музике. Опус који је заснован на недавно започетом раду на сакупљању грађе везане за живот и рад композитора словеначког порекла у Србији за сада је још увек непотпун и недовољно истражен, као а попис дела - нотног материјала, снимака извођења и друге архивске грађе.

Име које се најчешће помиње уз имена Корнелија Станковић, Стевана Стевановића Мокрањца и Јосифа Маринковића, јесте име Даворина Јенка и сврстава с међу најзначајније и најутицајније композиторе у Сpбији 19. века. Својим богатим опусом и разноврсним ангажовањима, Јенко је у знатној мери допринео развоју српске музике и формирању нових музичких и извођачких форми на српској музичкој и позоришној сцени. Поред утицаја на саму музичку уметност, Јенко је значајно утицао и оставио приметан траг и у самом обликовању модерног, урбаног Београда, учествујући у развијању позоришта и формирању опере, а основао је и више певачких друштава и хорова, што је у то време била значајна новина у животу града. 
Као што је напред речено, током 19. века, у времену снажних друштвених промена, повезивања уметника и научника са ових простора, у Србију су долазили ствараоци из иностранства, махом из Аустро-Угарске, а међу њима и Словенци. Школовали су се у европским универзитетским центрима, и било је доста уобичајено да ствараоци свој радни век проведу у више градова и држава.

Тако се међу најугледнијим именима београдске интелектуалне елите друге половине 19. века нашао и Даворин Јенко, који је највећи део свог живота провео у Србији, у коју је дошао после студија у Бечу, а на препоруку Корнелија Станковића. Даворин Јенко је рођен 1835, године у Словенији, у месту Дворје код Крања, а музичко образовање стекао је у Љубљани и Трсту (Прелић 2010 : 241). Боравак у Бечу, где је студирао права, омогућио му је да се упозна са панславистичким идејама својих савременика, што је имало значајан утицај на његово касније стваралаштво. Своју склоност и таленат за хорску музику показао је још у време студија, кад је за хор Словеначког певачког друштва написао неколико композиција са родољубивом тематиком, између осталог и композицију Найреј застиава славе, која је у народу касније заживела као незванична химна (Сабо $2010: 262)$.

Јенка је из Беча у Србију позвао угледни српски композитор Корнелије Станковић да започне свој рад као хоровођа Српског црквеног певачког друштва 1863. године у Панчеву. Убрзо прелази у престоницу, 1865. постаје диригент Београдског певачког друштва и активно се укључује се културни живот. Београдско певачко друштво Јенко је водио до 1977. године, а од 1871. до 1902. године ради и као капелник Народног позоришта у Београду. После пензионисања, односно после смрти 
своје животне сапутнице, велике глумице Веле Нигринове, вратио се у Љубљану где је умро 1914. године. О томе до које мере је био цењен Даворин Јенко у београдским културним и интелектуалним круговима сведочи његово чланство у Српском ученом друштву и Српској краљевској академији. Јенко није био заборављен ни у родном крају - био је изабран за почасног члана Музичке матице у Љубљани (Сабо 2010 : 262-264).

Посебан допринос Даворина Јенка музичкој уметности у Србији у другој половини 19. века огледа се у писању такозваних комада с певањем, који у српској култури тог времена представљају новину. Још у време студија у Бечу компоновао је на стихове Симона Јенка, Мирослава Вилхара, као и на стихове највећег словеначког песника, Франца Прешерна. Јенко је компоновао мелодију на Прешернове стихове Сируне мило се їласиие, као део позоришног комада Избирачица, у којем је певана као дует Зујӣе сиируне (Сабо 2010 : 263). На тај начин су стихови значајни за словеначку књижевност постали део српске музичке традиције.

Даворин Јенко је у српској музици запамћен као аутор музике за преко 90 позоришних комада, међу којима су посебно значајни наслови као што Врачара, дело које се сматра првом српском оперетом, Прибислав и Божана оцењен као Јенков најуспешнији комад, а посебно иступају увертире под насловима Косово, $\mathrm{Mu \text {- }}$ лан, Срӣкиња и Алексанgар. Често извођена на крају 19. века и почетку 20., ова дела не само шту су обележила београдски позоришни репертоар, него су утицала на стваралаштво српских композитора, а посебно је занимљиво то што је неке од најзначајнијих тема српске историје кроз музику овековечио један Словенац.

Име Даворина Јенка је данас свакако најпознатије због чињенице да је он аутор мелодије на стихове Јова- 
на Ђорђевића, Боже йравgе, песме која је проглашена званичном српском химном. Песму Боже йравgе Јенко је компоновао 1872. године као финални део комада с певањем Маркова сабља. Овај комад је био наручен за прославу пунолетства Милана Обреновића и после премијерног извођења у Народном позоришту постала је веома популарна. Приликом проглашења Краљевине Србије 22. фебруара 1882. песма Боже йравgе изведена је као државна химна, уз мала прилагођавања текста за ове потребе (Маринковић 2009 : 47). Иако је 1903. расписан званични конкурс за нову српску химну на којем су изабрани стихови Алексе Шантића Боже,на йоља земље ове Јенкова мелодија и Ђорђевићеви стихови су били толико популарни, да је краљ Петар Карађорђевић 1909. године издао указ о прихватању песме Боже üpaвge за српску химну. У периоду постојања Краљевине Срба, Хрвата и Словенаца, постојале су три химне: српска је и даље била Боже йравgе, хрватска Лијейа наша, а словеначка Найреј, засйава славе. Јенко је, дакле, био аутор мелодије две химне у периоду Краљевине СХC: српске и словеначке. Током постојања СФРЈ званична химна је била Хеј, Словени, али по распаду заједничке државе и формирању нових држава на овим просторима, песма Боже йравgе је чланом 7 Устава Републике Србије из 2006. године проглашена званичном химном Републике Србије (Ђукановић 2015 : 112).

Културни живот Београда у другој половини 19. века обележило је постојање певачких друштава у која су се учлањивали певачи-аматери, за које су писане једноставније композиције. Њихова тематика је често почивала на фолклорној традицији, са јасном и разумљивом родољубивом поруком. Ове песме су настајале у периоду романтизма и носећи у себи све карактеристике ове епохе, значајно су учествовале у формирању 
националне свести. Од песама таквог карактера од Јенкових су најпознатије Сабљо моја gимишћијо, Шӣо ћу-

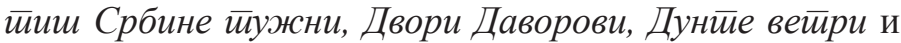
сличне. Сарађујући са познатим песницима и писцима тог времена, Јенко је писао музику на њихове текстове, међу којима су посебно значајна дела Сеоба Србаља на текст Ђуре Јакшића и Ђugo на текст Јанка Веселиновића (Сабо 2011 : 2). Рабла на улазу у београдски Факултет музичке уметности, садржи захвалност „првим трудбеницима и организаторима музичке културе у шумадијским странама“: Корнелију Станковићу, Јосифу Маринковићу, Стевану Ст. Мокрањцу и Даворину Јенку, београдском Словенцу.

Међу значајним Словенцима који су живели и стварали у Београду, истиче се и име Миховила Логара, рођеног у Ријеци 1902. године. Логар је у Београд дошао1927. године, после школовања у Прагу, где се упознао да културном традицијом других словенских народа. У Београду је најпре радио у Музичкој школи, затим у Средњој музичкој школи, а од 1940. постаје предавач на Музичкој академији, развијајући идеје и рад генерације такозване прашке групе композитора, која је обележила професионални развој музичког живота Србије (Сабо 2010 : 265).

Логарово стваралаштво је обележено оптимизмом, ведрином и духовитошћу, а његов опус је изузетно богат и по броју дела и по разноврстности музичких жанрова. Композиције чији је Логар аутор су често настајале на стихове и прозне текстове еминентних књижевника. О томе сведоче наслови Логаревих опера: Четири сцене из Шекспира (1931), Саблазан у долини Шентфлорјанској (1938), Покондирена тиква (1954), и Четрдесет прва (1959). Логар је либрето за дело Саблазан у долини шентфлорјанској, музичка фарса у 
три чина написао сам, на основу познате сатире Ивана Цанкара, а либрето за Покондирену тикву написао је Хуго Клајн, на основу текста Јована Стерије Поповића. У његовом опусу налазе се наслови као што су Плава гробница (кантата, 1934.) и Дундо Мароје (увертира, 1936.), а за хорска дела је често карактерисичан духовит текст. За Логара је карактеристично то што је био инспирисан ауторским књижевним текстовима, којима је повезивао различите културе и књижевне баштине.

Док је Даворин Јенко у широј јавности познат као аутор државне химне, Миховил Логар је познат пре свега као аутор својеврсне химне Београда. Његова Песма Беоіраgy годинама је емитована на почетку и на крају програма Радио-телевизије Београд, а извођена је и у различитим свечаним приликама. Са преко 200 дела, Миховил Логар се уврстио међу најзначајније композиторе у Србији. Умро је у Београду 1998. године, као угледан композитор, професор Факултета музичке уметности и вишегодишњи председник Удружења композитора Србије (Сабо 2010 : 265-266).

Српску хорску музику обележио је и уздигао на изузетно висок ниво још један Словенац - Златан Вауда, чије се име везује за Дечји хор Радио-телевизије Србије. Породица Вауда је у Србију дошла на почетку Другог светског рата из родне Шмарјете код Марибора. Златан Вауда, рођен 1923. године, је још као дечак прва музичка знања стекао у кругу породице, а музика је обележила читав његов животни пут. На београдској Музичкој академији је завршио студије у класи професора Марка Тајчевића, а у свом професионалном раду се посветио пре свега хорској музици. За собом је оставио опус који броји преко 300 дела. По сопственом потресном сведочењу, дела Златана Вауде обележила су три акорда која је записао у Крагујевцу 21. октобра 1941, када је само 
игром случаја избегао стрељање (ц ${ }^{1} \Gamma^{1} Ц^{2} e c^{2}-д^{1}$ гис ${ }^{1} д^{2}$ фис ${ }^{2}-\mathrm{ec}^{1} \mathrm{a}^{1}$ д $^{2}$ фис ${ }^{2}$ ), а та три акорда су уткана у његове касније композиције (Сабо 2003 : 33).

Златан Вауда је од 1952. до 1986. био диригент и педагог дечијег хора РТВ, који је значајно утицао на развој хорске музике у Србији. Репертоар хора у великој мери је надмашивао стандардне дечје хорске композиције, а извођена су изузетно компликована дела домаћих и страних композитора. На тај начин је на веома високом нивоу промовисано стваралаштво домаћих композитора хорске музике. Вауда је био активан као музички педадог, али и као композитор камерне уметничке музике.

Повезаност са српском књижевном традицијом показао је на више начина. На пример, на текст Бранка Ћопића компоновао је дечју оперу Јежева кућица (1957.), која је извођена у више позоришта. Ваудин опус често се базира на фолклорној традицији, било да је у питању компоновање на стихове и мотиве из народне традиције, било да су у питању обраде изворних народних песама. На тај начин настала је збирка обрада фолклорних мелодија под насловом Звуции моїа завичаја, а у Ваудином опусу налази се и велики број песама из НОБ-а. Дела Златана Вауде која је написао за камерне саставе и оркестре, често су медитативна, мрачна и тешка. Пример за то је триптих Сеансе, премијерно изведен 1974. године, у којем Вауда комбинује

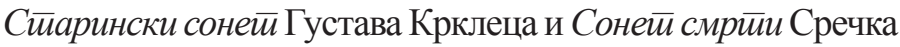
Косовела, опет повезујући различите књижевне баштине.

\section{6. Закључак}

Преплитања и међусобни утицаји српске и словеначке културе и уметности обухватају бројне примере из различитих подручја стваралаштва - књижевности, 
музике, сликарства, позоришта, филма - од којих је у овом прилогу представљен само мањи део. Током седамдесет година Словенија и Србија су биле део заједничке државе, за коју је била карактеристична политика систематичног међукултурног посредовања. Резултат тога су многа заједничка достигнућа у култури и науци, као и бројни међусобни утицаји које ваља истражити са различтих аспеката. Српско-словеначке међукултурне студије садрже читав низ непроучених и неистражених тема, тако да словеначки елементи који су заступљени у урбаној микротопонимији Београда, могу бити полазна тачка за многа даља проучавања, којим би се осветлили многи међусобни контакти и утицаји два блиска јужнословенска народа.

\section{Цитирана литература:}

Ђукановић, Маја 2015 Поглавља из словеначке културе. Београд: Филолошки факултет.

Гспан, А. ет ал. (1967). Словенски биоірафски лексикон: 10. зв. Сихмиял - Сиеклласа. Љубљана, Словенска академија знаности ин уметности.

Гспан, А. ет ал. (1971). Словенски биоірафски лексикон: 11. зв. Сйелѐ - Швикариич. Љубљана, Словенска академија знаности ин уметности.

Кржишник - Букић, Вера 2003 Словенци в Хрвашки, Босни ин Херцеговини, Србији ин Чрни гори тер Македонији. Традитионес 32 (2): 117-135

Лукман, Ф. (1935). Словенски биоірафски лексикон: 6. 36. Мркун - Пеиерлин. Љубљана, Задружна господарска банка.

Маринковић, С. (2009). Исйорија срйске музике. Београд: Завод за уџбенике и наставна средства.

Норис, Дејвид (2002). Балкански мит. Питања идентитета и модерности. Београд: Геопоетика. 
Прелић, М. (2010). Како йамйимо Даворина Јенка. У: Ингрид Славец Градишник и Драгана

Радојичић (ур.) Словенци в Србији, Срби в Словенији, стр. 239-260, Љубљана, ЗРЦ САЗУ

Прошић-Дворнић, Мирјана (2006). Оgевање у Беоіраgy у ХИХ и йочетиком ХХ века. Београд: Стубови културе.

Сабо, Адриана (2012). Комйозитиори словеначкой йорекла у Србији. Београд: Национални савет словеначке националне мањине.

Сабо, Аница (2003). Три акорgа Злайана Вауgе. Нови звук. стр. 28-33. Београд.

Сабо, Аница. (2010). Словеначки комйозийори у Србији. Даворин Јенко, Миховил Лоїар. У: Ингрид Славец Градишник и Драгана Радојичић (ур.) Словеничи в Србији, Срби в Словенији, стр. 261-273, Љубљана, ЗРЦ САЗУ.

Стеле, Ф. (1974). Орис зіодовине сликарстива в Словенији, Словенски језик, литература ин култура, Информативни зборник. ССЈЛК, Филозофска факултета Универзе в Љубљани, стр. 267-278. 


\title{
Prof. Maja Đukanović, PhD \\ University of Belgrade Faculty of Philology
}

\section{SERBIAN-SLOVENIAN INTERCULTURAL STUDIES THROUGH THE PRISM OF URBAN MICROTOPHONYM OF BELGRADE}

\begin{abstract}
Summary
Belgrade, as an important cultural center in the Balkans, attracted many people - from artists and scientists who came to develop their careers, to people who immigrated in search of a better everyday life. Historical circumstances changed, political systems were replaced, the borders of the common state changed, and after more than seven decades of existence in a common state, Serbs and Slovenians continued their development in separate entities. During the period spent in a common state, they have left a recognizable trail not only in the field of culture and art, but also the mutual influence observed in other spheres of life. The interweaving and interplay of Serbian and Slovenian culture and art involve numerous examples from various fields of creativity - literature, music, painting, theater, film - of which only a small part will be presented in this paper.
\end{abstract}

Key words: Belgrade, culture, art, literature, Serbian-Slovenian intercultural studies. 